\title{
Swidden, Rubber and Carbon Can REDD+ work for people and the environment in Montane Mainland Southeast Asia?
}

Working Paper No. 9

Jefferson Fox Jean-Christophe Castella Alan D. Ziegler

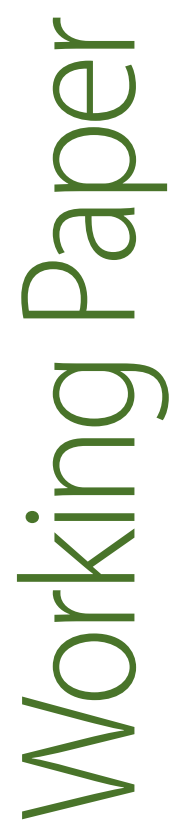




\section{Swidden, Rubber and Carbon Can REDD+ work for people and the environment in Montane Mainland Southeast Asia?}

Working Paper No. 9

CGIAR Research Program on Climate Change, Agriculture and Food Security (CCAFS)

Jefferson Fox Jean-Christophe Castella Alan D. Ziegler 
Correct citation:

Fox J, Castella J-C, Ziegler AD. 2011. Swidden, Rubber and Carbon: Can REDD+ work for people and the environment in Montane Mainland Southeast Asia? CCAFS Working Paper no. 9. CGIAR Research Program on Climate Change, Agriculture and Food Security (CCAFS). Copenhagen, Denmark. Available online at: www.ccafs.cgiar.org

Titles in this Working Paper series aim to disseminate interim climate change, agriculture and food security research and practices and stimulate feedback from the scientific community.

Published by the CGIAR Research Program on Climate Change, Agriculture and Food Security (CCAFS).

CCAFS Coordinating Unit - Department of Agriculture and Ecology, Faculty of Life Sciences, University of Copenhagen, Rolighedsvej 21, DK-1958 Frederiksberg C, Denmark. Tel: +45 35331046; Email:ccafs@life.ku.dk

Creative Commons License

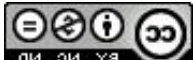

This Working Paper is licensed under a Creative Commons Attribution - NonCommercial-NoDerivs 3.0 Unported License.

Articles appearing in this publication may be freely quoted and reproduced provided the source is acknowledged. No use of this publication may be made for resale or other commercial purposes.

(C) 2011 CGIAR Research Program on Climate Change, Agriculture and Food Security (CCAFS) 2011 CCAFS Working Paper no. 9

DISCLAIMER:

This Working Paper has been prepared as an output for the Pro-Poor Mitigation Theme under the CCAFS program and has not been peer reviewed. Any opinions stated herein are those of the author(s) and do not necessarily reflect the policies or opinions of CCAFS.

All images remain the sole property of their source and may not be used for any purpose without written permission of the source.

Working Paper layout: Vanessa Meadu and Alison Nihart 


\section{Other Related CCAFS Working Papers}

This paper was produced in collaboration with Arun Agrawal and Lauren Persha at the University of Michigan for the project Governing Mitigation Trade-offs in AgricultureForestry Landscapes. See other related titles:

CCAFS Working Paper no. 7. Robinson BE, Holland MB, Naughton-Treves L. 2011. Does secure land tenure save forests? A review of the relationship between land tenure and tropical deforestation.

CCAFS Working Paper no. 8. Börner J, Wunder S, Wertz-Kanounnikoff S, Hyman G, Nascimento N. 2011. REDD sticks and carrots in the Brazilian Amazon: Assessing costs and livelihood implications.

CCAFS Working Paper no. 10. Barbier EB and Tesfaw AT. 2011. Overcoming tenurial constraints to carbon forestry projects in Africa.

CCAFS Working Paper no. 11. Cohn A, Bowman M, Zilberman D, O’Neill K. 2011. The Viability of Cattle Ranching Intensification in Brazil as a Strategy to Spare Land and Mitigate Greenhouse Gas Emissions.

All papers available online at: www.ccafs.cgiar.org 


\section{Abstract}

Swidden (also called shifting cultivation) has long been the dominant farming system in Montane Mainland Southeast Asia (MMSEA). Today the ecological bounty of this region is threatened by the expansion of settled agriculture, including the proliferation of rubber plantations. In the current conception of REDD+, landscapes involving swidden qualify almost automatically for replacement by other land-use systems because swiddens are perceived to be degraded and inefficient with regard to carbon sequestration. However, swiddening in some cases may be carbon-neutral or even carbon positive, compared with some other types of land-use systems. In this paper we describe how agricultural policies and institutions have affected land use in the region over the last several decades and the impact these policies have had on the livelihoods of swiddeners and other smallholders. We also explore whether incentivizing transitions away from swiddening to the cultivation of rubber will directly or reliably produce carbon gains. We argue that because government policies affect how land is used, they also influence carbon emissions, farmer livelihoods, environmental services, and a host of other variables. A deeper and more systematic analysis of the multiple consequences of these policies is consequently necessary for the design of successful REDD+ policies in MMSEA, and other areas of the developing world. REDD + policies should be structured not so much to 'hold the forest boundary' but to influence the types of land-use changes that are occurring so that they support both sustainable livelihoods and environmental services, including (but not limited to) carbon.

\section{Keywords}

REDD+; swidden; rubber; Mainland Southeast Asia; livelihoods; carbon 


\section{About the authors}

Jefferson Fox, Senior Fellow, East-West Center, 1601 East-West Road, Honolulu, Hawaii, USA; foxj@eastwestcenter.org

Jean-Christophe Castella, Institute of Research for Development, France and Centre for International Forestry Research, Indonesia; hosted at National Agriculture and Forestry Research Institute, Laos; j.castella@ird.fr

Alan D. Ziegler, Geography Department, National University of Singapore, geoadz@nus.edu.sg 


\section{Acknowledgements}

Many of the ideas are based in collaboration with several colleagues, including E.L. Webb, J.

Phelps and D. Lawrence. The work was also supported by the following projects: NASA

grants NNG04GH59G and NNX08AL90G; and Asia Pacific Network grants ARCP2007-

01CMY and ARCP2008-01CMY. 


\section{Contents}

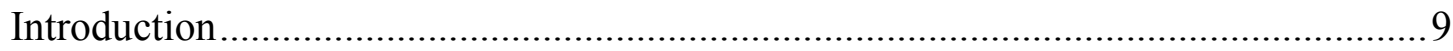

Rubber (Hevea brasiliensis) expansion in MMSEA .................................................. 12

Rubber Policies, Land Use, and Livelihoods in MMSEA .......................................... 13

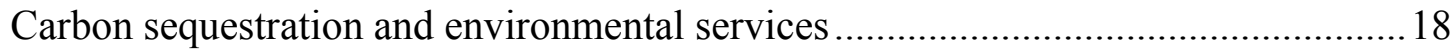

Conclusions and Recommendations: Landscapes, Livelihoods, and Carbon transitions

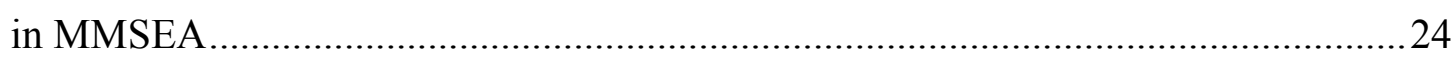

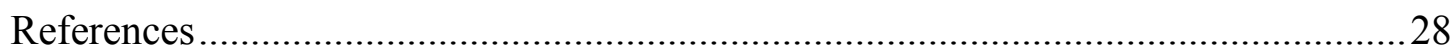




\section{Acronyms}

AGC

Above-ground carbon

BGC

Below-ground carbon

MMSEA Montane Mainland Southeast Asia

REDD+ United Nations Collaborative Programme on Reducing Emissions from

Deforestation and Forest Degradation in Developing Countries

SOC

Soil organic carbon 


\section{Introduction}

Efforts for Reducing Emissions from Deforestation and forest Degradation (REDD+) are expected to include payments to forest-rich developing nations by industrialized nations for achieving long-term reductions in carbon emissions by reducing the extent of deforestation and forest degradation, thereby protecting and enhancing carbon stocks (UNFCCC 2009). The REDD+ framework could also produce co-benefits including the maintenance of ecosystem services (e.g., preservation of species diversity) as well as the conservation of indigenous livelihoods and cultures (Gibbs et al. 2007; van Noordwick et al. 2009; Mertz 2009; Ziegler et al. 2011). The Conference of Parties (COP) held in Cancun in 2010 showed an increased interest in the role of agriculture in REDD+ debates, and in opening up the range of potential REDD+ beneficiaries from forest sector and forest-dependent populations (as initially designed during COP13 of the UNFCCC in Bali 2007) to include a larger range of stakeholders at the interface between forest, plantations, and agriculture (Campbell 2009; Negra and Wollenberg 2011) This recent evolution in the REDD+ political debates may provide an avenue for inclusion of agroforestry systems (i.e. complex landscape mosaics combining agriculture, managed forests and plantations), ranging from swidden agriculture systems to rural forests and smallholder plantations, into REDD+ schemes. The swidden landscapes of Montane Mainland Southeast Asia (MMSEA) form an arena where REDD+ debates are likely to have strong impact.

MMSEA, defined as land above $300 \mathrm{~m}$ elevation, covers about half the land area of Cambodia, Laos, Myanmar, Thailand, Vietnam, and China's Yunnan Province, and harbours an immense wealth of natural resources, including globally important stocks of forests and biological diversity, a rich heritage of indigenous cultures, and the headwaters of major river systems (Figure 1). For centuries swiddening (also called shifting or slash and burn agriculture) has been practiced in MMSEA by indigenous farmers who managed land in ways that integrated production from both cultivated fields and diverse secondary forests. The latter often included everything from grass and bushes, to young open-canopy tree associations, to mature closed-canopy tree communities (Cairns 2007). These diverse human-managed agricultural systems produced a unique landscape mosaic that combined both agriculture and forestry (Ramakrishnan et al. 2006, 2007). Indeed swiddening is not simply agriculture or 
forestry, but a comprehensive landscape management system that operates on a timescale that cannot be captured by a snapshot of an individual forest plot or field (Fox et al. 2009).

Figure 1 Traditional and non-traditional rubber growing areas in Mainland Southeast Asia based on provincial and state level statistics collected between 2007 and 2009.

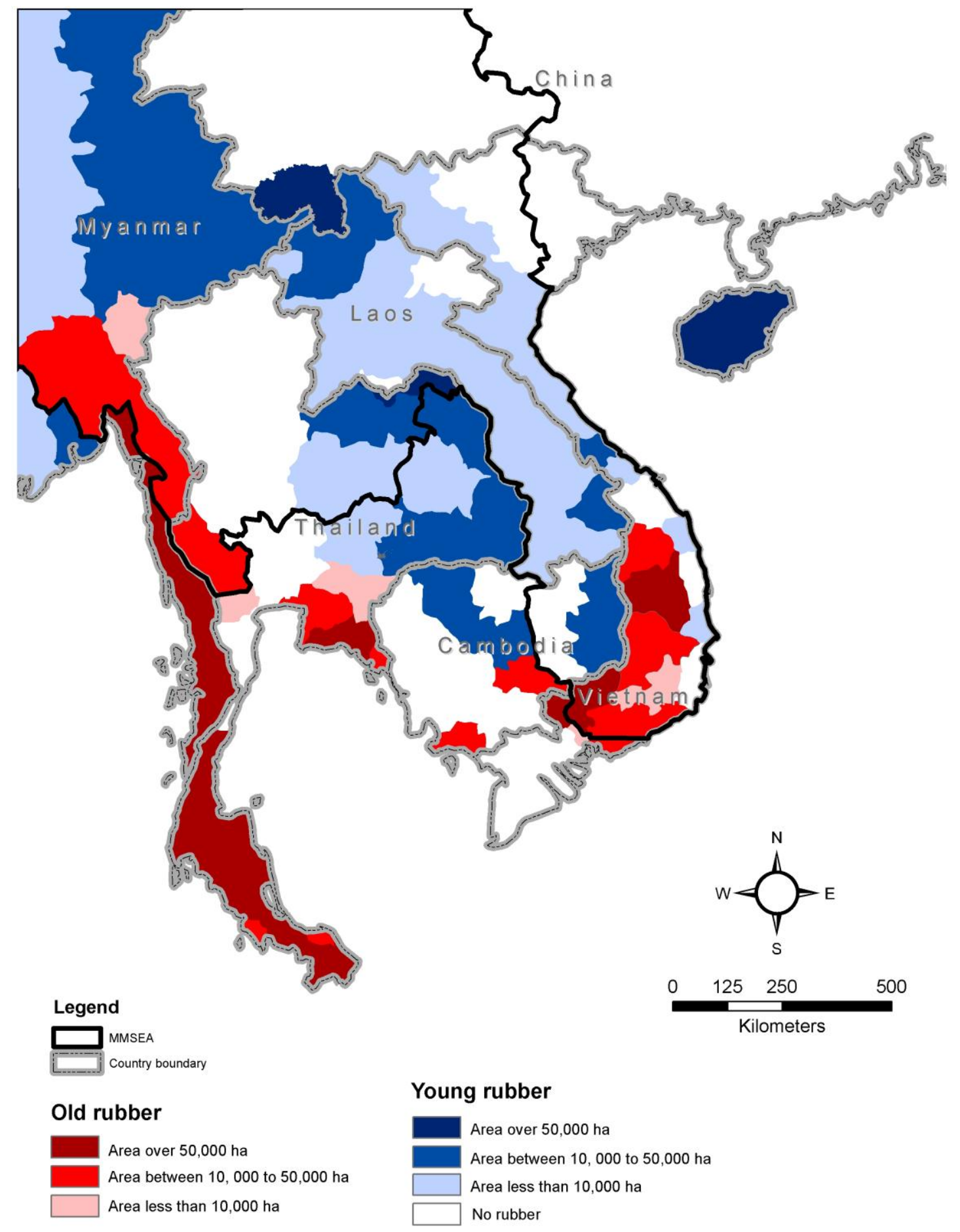

Many of the most dramatic changes in the global landscape during the twentieth century had their origins in agricultural policies. For example, national policies in MMSEA have included 
the outright banning of swiddening, declaring an area a forest reserve and excluding people, and resettling people into the lowlands. Governments have encouraged human settlements at such high population density that the fallow periods necessary for forest regeneration cannot be maintained, making sustainable swidden impossible (Padoch and Pinedo-Vasquez 2010; Fox et al. 2009). These policies also promoted and subsidized other forms of agriculture such as extensive, long-term cultivation of annual crops, tree crops cultivated in monoculture plantations (particularly rubber), and greenhouse-based horticulture (Rasul and Thapa 2003; Padoch et al. 2007; Schmidt-Vogt et al. 2009). Recently many farmers in the region have realized opportunities to convert their land to commercial crops; while other farmers have been encouraged or forced to convert. Through industrial agriculture schemes, entrepreneurs, corporations or governments often seek to gain control of swidden land in ways that range from outright dispossession of swiddeners to supposed "joint ventures" with corporate agricultural companies that take control of villagers' customary lands for lengthy periods of time (Ngidang 1997; 2002; Majid-Cooke 2003, 2006). Because agricultural policies affect how land is used, they affect carbon emissions, farmer livelihoods, environmental services, and a host of other variables. A deeper and more systematic analysis of the multiple consequences of these policies is consequently necessary for the design of successful REDD+ policies in MMSEA, and other areas of the developing world.

This paper addresses issues related to mitigation of carbon emissions in a context of land-use change within swidden systems (i.e., shortening of the fallow and/or lengthening of cropping periods) and conversion from swidden to rubber plantations. Swidden agriculture is rapidly disappearing in MMSEA as farmers are pushed by national policies and drawn by market forces towards high-value commercial crops. We first summarize the growing demand for rubber in MMSEA. We then examine the history of land-use policies in southern China and Laos to show that while policies in both countries are leading to an increasingly homogenous landscape dominated by rubber the impact of those policies on the livelihoods of smallholders and their food security diverge immensely. By extension we argue that REDD + policies that seek only to increase tree cover can have a range of impacts on smallholders' livelihoods that vary from beneficial to destructive. We then examine the differences in carbon storage in swidden fallows and rubber plantations to determine if any evidence exist that REDD+ policies that incentivize transitions from swidden to rubber will create carbon gains. Finally, we question whether it is possible to design REDD+ policies that are likely to contribute to 
the reduction of terrestrial emissions and also enhance development and food security objectives in MMSEA.

\section{Rubber (Hevea brasiliensis) expansion in MMSEA}

Rubber is a "hot commodity" with consumption increasing worldwide at an average rate of 5.8 percent per year since 1900 (Rubber Board 2005). Synthetic rubber accounts for approximately $57 \%$ of the total, but natural rubber is cheaper and of superior quality for highstress purposes. Jet and truck tires are almost entirely natural rubber. Prachaya (2009) forecasts that total rubber consumption will increase from 22.1 million ton in 2008 to 23.2 million tons by 2018; and the relative share of natural rubber will increase from $43 \%$ in 2008 to $48 \%$ by 2018 . Consumption of natural rubber is anticipated to increase from 9.6 million tons in 2008 to 13.8 million tons by 2018 - a growth of 3.7\% per year (Prachaya 2009).

Asia accounts for $97 \%$ of the world's natural rubber supply, with the vast majority coming from Thailand (31\%), Indonesia (30\%), and Malaysia (9\%). Rubber is native to the Amazon basin; and it has been historically cropped in the equatorial zone between $10^{\circ} \mathrm{N}$ and $10^{\circ} \mathrm{S}$ in areas with twelve months of rainfall. In mainland Southeast Asia this includes portions of southern Thailand, southeastern Vietnam, and southern Myanmar. In the early 1950s, in attempt to secure economic development, China invested heavily in research on growing rubber in environments perceived to be marginal in terms of cooler temperatures and having a distinct dry season. State rubber plantations were established in Hainan and Yunnan provinces in areas that lie as far north as $22^{\circ}$ north latitude. China's success in growing rubber in these 'non-traditional' environments greatly expanded the habitat in which rubber is planted. Hybrids are now grown at elevations exceeding 1000 m (Qiu 2009) and in areas with distinct dry seasons across most of MMSEA.

Today, entrepreneurs from China, Vietnam, Malaysia, and Thailand are investing heavily in rubber plantations in non-traditional rubber growing areas of Laos, Cambodia, and Myanmar, as well as in non-traditional rubber growing areas of their own countries - northwest Vietnam, and northeast Thailand. As shown in Fig 1 this is primarily the area we defines as MMSEA with the addition of areas in northeast Thailand and western Cambodia. The National Agriculture and Forestry Research Institute suggests that more than 140,000 ha of rubber have been planted in Laos in the last decade and that the plantation area may reach 300,000 ha 
during the next decade (Douangsavanh 2009). In Cambodia, the Ministry of Agriculture plans to expand the area under rubber cultivation from 100,000 ha to as much as 800,000 ha by 2015. In Myanmar, rubber is expanding into border areas in Kachin and Shan States. In Thailand, rubber has expanded to include over 64,000 ha in the north and 348,000 ha in the northeast. The rubber growing area in Vietnam increased from 395,000 ha in 1999 to 550,000 ha in 2007 with 4,500 ha planted in the northwest region. The government has a target of 700,000 ha of rubber by 2020 . Collectively more than $1,000,000$ ha of rubber have been planted in the last several decades in non-traditional rubber growing areas of China, Laos, Thailand, Vietnam, Cambodia, and Myanmar (Li and Fox submitted). By 2050, the area of land dedicated to rubber (and/or other monoculture plantation crops) in these areas could quadruple, largely by replacing lands now occupied by evergreen broadleaf trees and swidden-related secondary vegetation (Fox et al. submitted).

\section{Rubber Policies, Land Use, and Livelihoods in MMSEA}

Over the last half-century, government policies and institutions have affected land-use practices across the borders linking China, Thailand, Laos, Vietnam, Cambodia, and Myanmar. Political and economic reforms have facilitated labor mobility and a shift in agricultural practices away from swiddening and towards a diverse array of cash crops, rubber being one of the foremost (Ziegler et al. 2009a). The impact of rubber on smallholders, however, varies immensely. In the largest rubber producing countries, the smallholder sector dominates production: $93 \%$ of rubber in Malaysia, $90 \%$ in Thailand, $89 \%$ in India, and $85 \%$ in Indonesia (Rubber Board 2005). Rubber presents an interesting opportunity for smallholders as it can be intercropped on a short rotation, making it more attractive than plantation crops that require a longer period before a product can be harvested. In addition, it can be intercropped both during the years before tapping as well as placed within the context of a longer-term agroforestry systems (Michon et al. 2007). Indeed, Viswanathan and Shivakoti (2008) suggest that rubber cultivation, when integrated into existing farming systems, can result in significant increases in household income and greater resilience in the face of volatile markets. While the intensity of production of rubber grown in a diversified agroforestry system is lower than that of monoculture rubber (and may even vary inversely with market prices), rubber grown in an agroforestry system provides smallholders with 
independence from external economic and political influences. This independence has been a key to their historical success.

Fox and Castella (submitted) examined the different types of rubber farming that are developing in the region and explored the impact these systems are having on local livelihoods in China, Laos, Thailand, Cambodia and Myanmar. Here we will review the situations in China (Xishuangbanna Prefecture, Yunnan Province) and Laos. Between 1978 and 1983 the Chinese government implemented the Household Responsibility System which dismantled the farming communes and introduced a new ideology of land use, turning farmers into entrepreneurs responsible for caring for their own needs by giving them long-term lease rights to agricultural land. In 1983, Yunnan Province implemented a policy called liangshanyidi (freehold and contracted forestlands and swidden fields), which had the objective of stabilizing forest lands and swidden fields through land titling and demarcation. The main goal of this reform was to shift forest management from the state to individuals for forest regeneration by leasing or contracting forest lands to individuals (Xu et al 2006). China considers rubber plantations as forests and consequently includes them in the forest land data they provide to FAO Forest Resource Assessment database http://www.fao.org.

The government also undertook a major state campaign to encourage upland farmers to plant rubber at elevations below $700 \mathrm{~m}$ in fields used for swiddening, and later subsidized a state anti-poverty campaign encouraging farmers to plant rubber on sloping lands. In 2002, the "Grain for Green" campaign was introduced to promote the development of China's western provinces and protect the environment; this program provided farmers with grain for eight years if they planted forest cover on degraded slopes. In Xishuangbanna Prefecture, authorities began counting rubber trees as forest cover about the same time a rapid rise in rubber prices occurred. Eager for wealth, households began planting rubber in their traditional woodlots, in village forests, and on the remaining and steeper slopes. Below $700 \mathrm{~m}$, but even higher, rubber became ubiquitous.

Today, rubber farmers in Xishuangbanna have achieved unprecedented wealth. Sturgeon (2010, p. 325) quotes an Akha rubber farmer as noting that "Money is the most important thing; money makes everything possible." That 'everything' includes sending their children to high school, and for some, on to university; buying insurance for retirement and health care; and even a holiday in the city for an entire village. Indeed Sturgeon argues some ethnic- 
minority rubber farmers in Xishuangbanna have achieved a standard of living today that has more in common with middle-class urban residents than with most fellow farmers.

The rubber success story in China is considered by other countries in the region as an example of a win-win strategy for increasing forest cover while alleviating poverty in remote rural areas and generating income from export commodities. While desiring to emulate China's success with the introduction of rubber as a crop, many of these countries have not initiated policies that provide secure access to land (long-term lease rights in the case of China), or provided extension services and subsidies the Chinese did through programs like Grain for Green.

In Laos, what began as a modest supplemental farm enterprise to enhance livelihoods for upland farmers grew rapidly into an expanding agro-industry that is becoming shrouded in mounting concerns over a lack of governmental regulation and controls (Douangsavanh et al. 2008). Due to the immature nature of the industry government officials in Laos have relied on external inputs of knowledge and investments from state and private entrepreneurs from neighboring countries, particularly China, Vietnam and Thailand. These investments have triggered a sudden and huge increase in rubber planting, especially in northern and southern provinces. As a result of poor governmental regulations and enforcement strategies, a large range of institutional arrangements for rubber production have emerged in recent years. These arrangements are categorized as smallholders, contract farming, and concessions with a number of variations in each type according to who provides the main factors of production (i.e., land, labor, capital, market outlet and technical knowledge). How contracts and concessions are negotiated between farmers, companies, and government agencies greatly influences rubber trajectories at the village level. Investors prefer the concession arrangement as a way to protect their investments; smallholders are concerned that these arrangements limit their access to knowledge, land, and profits.

Normally only applied to state land, concessions are negotiated by senior government officials and large tracks of land left under direct management by a company with limited interactions with local populations. Labour is frequently of foreign origin, which limits the transfer of technology to local farmers. In some cases, companies are allocated rights to prospect and negotiate with villagers for land deemed physically appropriate and accessible, but whose availability is uncertain and subject to local approval. The resulting model of rubber 
development is then a joint venture between foreign investors and farmers in a contract farming arrangement. Inputs and profits are supposed to be shared as determined by negotiations among investors, district authorities, and village representatives.

Two main kinds of contracts can be identified: 1) a ' $2+3$ ' model where farmers provide land and labour, and the company provides capital (in the form of seedlings, fertilizer and other equipment), technology, and access to markets; and 2) a ' $1+4$ ' model where farmers provide land and the company hires labour (perhaps the contracted farmer), capital, technology, and market access. When the trees become productive (approximately 7 years after planting) benefits are shared according to conditions agreed upon in the initial contract —under ' $2+3$ ' usually $70 \%$ of the benefits go to the farmers and $30 \%$ to the company, under ' $1+4$ ' usually $30 \%$ to the farmers and $70 \%$ to the company, sometimes benefits are split equally. The government, eager to support the emergence of a smallholder-based rubber industry, has actively promoted the ' $2+3$ ' model, while the investors eager to secure their investment and profits have pushed for the ' $1+4$ ' model. If farmers become too indebted waiting for their trees to become productive (7 years), investors can acquire the farmers' land tenure rights and convert them into concession-type tenure.

Smallholder rubber arrangements, however, can emerge even in places where rubber companies are actively promoting other institutional arrangements. Farmers with relevant knowledge (e.g., many villagers located close to the borders with China and Thailand have worked on rubber farms in these countries), capital (e.g., better-off farmers with good relations with district authorities) and agency (e.g., belong to farmers' groups) can negotiate advantageous arrangements that limit the role of investors as credit providers, or even resist companies' offers if they have already secured market access on their own (e.g., villagers in Sangthong district as documented by Castella et al. 2008).

Other issues that plague contract farming include inadequate village consultation, varying degrees of coercion, inconsistent understanding and interpretation among contracting and governing parties, low levels of technology transfer from investors to villagers, and disputes over land and wages (Shi 2008). Contracts between foreign investors and farmers are often vaguely written or non-existent, and pose a major concern for farmers because it is unclear who will benefit from the profits of rubber planting. The notion of a contract and its sanctity are not well understood by either investors or farmers in Laos. For example, some contracts 
are not legally binding due to lack of jurisdiction. In development projects involving land concessions, several undesirable aspects have emerged: e.g. uncompensated loss of assets, both private villager assets and state/public assets; uncompensated loss of resource entitlements by villagers (e.g. non-timber forest products) and of public goods (e.g. watershed protection services) by the state; and configurations of resource use that secure resource control but decrease net benefits, and that in doing so fail to capitalize effectively on the overall comparative advantages of the country (Douangsavanh et al. 2008; Baird 2010).

We have discussed the situation in some detail in Laos because one of the co-authors (Castella) is currently conducting research in the country. While we have less data to support it, the situation for smallholders in Cambodia and Myanmar appears to be worse. In both countries farmers have been forcibly relocated for rubber plantations, employed by armed groups to establish tracts of rubber, and coerced into planting rubber themselves due to landuse restrictions (see Undercurrents 2009, Fox et al. 2008). In Thailand, the situation for smallholders is much better. The Thai Office of Rubber Replanting Aid Fund (ORRAF), a government supported institutions, assists smallholders by providing free or subsidized inputs and credit, extension information, provides low-cost credit, and supports community organizations and the formation of rubber cooperatives. ORRAF also supports smallholder activities such as fish ponds, livestock, crops, and handicrafts in order to aid farmers to maintain their livelihoods between the time they plant rubber and begin to tap.

As seen in these examples from China and Laos, national policies affect how the transition between traditional farming and commercial rubber production impacts the livelihoods of smallholders. As the Xishuangbanna model shows swidden farmers can manage access to and use of their lands, given appropriate support (e.g., recognition of long-term use rights), and provided with extension services and subsidies during the initial period when the rubber is being planted and becoming productive. It is clear that smallholder rubber production is a viable and effective proposition in moving households and communities out of poverty. On the other hand, externally imposed, large-scale policies (such as commercial estates being established in Laos) affect swidden farmers adversely. Even when laws and ordinances have been drafted that could assist smallholders to maintain control over their land and invest in commercial crops, lack of financial and human resources and competing policy and political agendas have prevented these measures from being implemented effectively. Consequently in 
many communities villagers are selling their land and migrants are moving into the areas. In other communities farmers are struggling to maintain community lands and forests in the face of growing pressures from investors and government institutions to impose concession arrangements.

Fox and Castella (submitted) suggest that in order to promote the establishment of a vibrant smallholder rubber sector the state must effectively implement national policies and institutional structures to support smallholder rubber cultivators. National legislation needs to be developed that recognizes customary claims to swidden fallows and grants farmers and farming communities legal access to the land they have traditionally used through either secure tenure or long-term use rights. In addition to access rights, governments need to develop agencies that provide integrated access to technology, capital, markets, labour, and knowledge (Ribot and Peluso 2003). An example of this is the services provided by the Offices of Rubber Replanting Aid Fund (ORRAF) in Thailand (Douangsavanh et al. 2008). It could also be useful to establish a governing and coordinating body to work closely with all sectors related to the rubber industry. At the local level, smallholder farmer groups need to be organized and/or supported in order to strengthen rubber cultivation, tapping, processing and marketing. We argue by extension that similar institutional arrangements will be imperative for implementing REDD+ policies if we seek to support the sustainability and economic viability of smallholders' production.

\section{Carbon sequestration and environmental services}

Under a REDD+ scenario, landscapes involving swiddening qualify almost automatically for replacement by other land-use systems - including rubber — because swidden lands are perceived to be degraded and inefficient with regard to carbon sequestration (Bruun et al. 2009; Mertz 2009). Swiddening, however, includes a wide range of land-use and management practices that affect carbon cycling differently. For example, pioneer swiddening involves cutting plots in primary forest, then cultivating for a few years before new plots are established elsewhere, and allowing regeneration of mature secondary vegetation on former cultivated plots. In comparison, rotational swiddening involves moving from plot to plot within the same landscape after short ( $<5$ years), intermediate (5-10 years), or long (10-25+ years) fallow periods. 
Recent syntheses aimed at increasing understanding of plausible biomass or carbon stock changes expected with land-cover conversion provide insight on a few major end member land covers such as forest, tree plantations, crop-lands, and grasslands, but they lack attention to swidden and rubber per se (e.g., Guo and Gifford, 2002; Murty et al. 2002; Gibbs et al. 2007; Don et al. 2011; however see Bruun et al. 2009). Although rubber could be lumped into a general plantation category, lack of specific attention to this important contemporary land cover stems from the fact that only recently has it been planted in plantations at scales large enough to be of environmental concern in MMSEA (Qui 2009; Ziegler et al. 2009a). Again, more than a million ha of land have been converted to rubber in MMSEA; and this area is expected to increase 4 fold over the next few decades (Fox et al. submitted). Many of the lands expected to give way to rubber are associated with swiddening (Fox et al. submitted). Swidden systems are unique in that they form a dynamic land cover, for which biomass and carbon stocks change dramatically over time between the planting and mature fallow phases. While the burning phase results in the emission of $\mathrm{CO}_{2}$, this loss may be offset to some degree by carbon sequestered during the fallow phase (Mertz 2009; Geist and Lambin 2002; FCPF 2010). Depending on land-use history, length of fallow, and the degree of disturbance during the cultivation phase, successive fallow regrowth includes vegetation associations ranging from poor-quality grasslands to mature secondary forests that are high in biomass and species diversity (Lawrence 2004; 2005; Cairns 2007; Bruun et al. 2009; Messerli et al. 2009; Rerkasem et al. 2009; Ziegler et al. 2011). While swidden systems potentially vary greatly in their ability to sequester carbon, they are nevertheless often lumped into a single category representing a principal agent of forest degradation, deforestation and carbon emissions (Mertz 2009; Geist and Lambin 2002; FCPF 2010).

Biome-averaged above- and below-ground carbon biomass estimates for tropical forests range from about 75-250 Mg C/ha (Gibbs et al. 2007), but values at individual sites may be much higher (e.g., Yamakura et al. 1986; Zheng et al. 2006). For example, in a rubber growing region of Xishuangbanna prefecture, Yunnan Province, China, Lu et al. (2010) estimated that the total above- and below ground carbon stock in a tropical seasonal forest ranged from 272 to $377 \mathrm{Mg} / \mathrm{ha}$, with almost a third being associated with the top one meter of soil. In comparison, above-ground carbon (AGC) stocks for rubber (13-61 Mg/ha) were only 13-50\% of those (105-122 Mg/ha) estimated for forests in Xishuangbanna (Li et al. 2008). The great 
variation was related to the relatively high elevations $(>800 \mathrm{~m})$ at which rubber clones were being grown. Outside MMSEA, AGC stock estimates in Brazil, Ghana, Hainan, Indonesia, and Thailand range from 60-103 Mg/ha (Van Noordwijk et al. 2000; Cheng et al. 2007; Wauters et al. 2008). The wide range of reported AGC stocks (13-103 Mg/ha) associated with mature rubber stands globally demonstrate that this tree-based land cover could sequester substantially less carbon than various types of mature swidden fallows (Brown and Lugo 1990; Jepson 2006).

For swidden systems, unless the fallow remains in a degraded, arrested grassland state, the biomass of advanced fallows should resemble that of secondary forests (Sabhasri 1978; Schmidt-Vogt, 2001). A great range in biomass and species diversity should however be expected depending on disturbance history, as well as, contemporary forest use and fallow management (Lawrence et al. 2005; Nikolic et al. 2008). Biomass accumulation rate may also decline with each cycle of swiddening (Lawrence et al. 2010). For example, forest regeneration on former swidden fields in Thailand that were repeatedly cultivated (with opium) for long periods prior to fallowing, recovered more slowly than those generating on former rice fields that were cultivated less intensively (Fukushima et al. 2008). Total biomass after 20-29 years for all former upland rice and opium sites in Thailand was 12-52\% (31-126 $\mathrm{Mg} / \mathrm{ha}$ ) of that in forests never cultivated (242 Mg/ha). For 30-49 year fallows, total biomass increased to $161-228 \mathrm{Mg} /$ ha (Fukushima et al. 2008). Assuming carbon comprises $50 \%$ of the biomass (Gibbs et al. 2007), these values equate to AGC stocks of $15-63 \mathrm{Mg} / \mathrm{ha}$ and $80-114$ $\mathrm{Mg} / \mathrm{ha}$ for 20-29 and 30-49 year recovery periods. Similarly, biomass data from a site in northwestern Vietnam (Tran et al. 2010) suggest that AGC in secondary forests would be about 60 and $96 \mathrm{Mg} /$ ha after 30 and 60 years. Elsewhere, Jepson (2006) working on swidden fallows in Sarawak reported carbon stocks of 2-5, 17-29, 19-35 Mg/ha for two, four, and tenyear fallows. These values are in agreement with summarized carbon accumulation rates for fallows 0-20 years of age (2-3.5 Mg C/ha/year; Lugo and Brown 1992).

Of importance to our comparison between rubber and swidden carbon sequestration, mature (> 10 years) fallow AGC values in Sarawak, Thailand, and Vietnam (20-114 Mg/ha) have substantial overlap with the $13-103 \mathrm{Mg} /$ ha range associated with rubber. Although caution is needed in directly comparing between different sites, the overlap in carbon biomass estimates prevents one from concluding unequivocally that rubber plantations sequester more above- 
ground carbon than swidden fallows - at least until the time when the sites are again cleared, and potentially, burned. This assertion still generally holds even if we consider the carbon extracted during tapping, which is on the order of $24 \mathrm{Mg} / \mathrm{ha}$ over a 30 -year period (Cheng et al. 2007).

Stocks of below-ground carbon (BGC) on most tropical land covers are largely uncertain. For forests a value of $20 \%$ of the AGC is often used as a conversion factor (Gibbs et al. 2007). Studies in Xishuangbanna, Thailand, and Malaysia suggest that BGC ranges from 10-33\% of the AGC values (Yamakura et al; 1986; Zheng et al. 2006; Kenzo et al. 2009). For a post-fire secondary forest site in Sarawak, the maximum rooting depth was $2.3 \mathrm{~m}$, with most trees roots extending down only one meter. Thus, if the Sarawak study is representative of secondary forests in general, it is plausible that mature swidden fallows elsewhere might also have shallow root systems with BGC values that are $\leq 20 \%$ AGC. As with swidden fallows, too few data exist to derive definitive BGC estimates in rubber plantations in the region. Data from Hainan (PRC), Thailand, and Cambodia suggest BGC for rubber ranges from 10-30\% of the AGC values (Cheng et al. 2007; Gnanavelrajah et al. 2008; Mizoue et al. 2009. As with AGC, the few BGC data that do exist for rubber and swidden, once again do not allow us to unequivocally state that either land cover sequesters more carbon than the other in this component.

Soil organic carbon (SOC) also comprises an ambiguous percentage of the total carbon associated rubber and swidden landscapes. This uncertainty is important because the SOC fraction could be large, depending on the soil depth. In Indonesia the soil carbon stock was about $90 \mathrm{Mg} / \mathrm{ha}$ in permanent rubber agroforests and $50 \mathrm{Mg} / \mathrm{ha}$ in more intensively managed rotational rubber plantations (Palm et al. 2005; Bruun et al. 2009). Bruun et al. (2009) concluded that stocks of SOC in rubber plantations were $0-30 \%$ lower than those in traditional swidden systems. They also pointed out that the soil quality in some farmer-managed unfertilized rubber gardens with relatively low intensity of tapping was similar to secondary forests associated with swiddening. However, negative soil impacts were greater in situations of intensified rubber cultivation where topsoil removal and compaction substantially altered physical properties.

A recent syntheses of SOC changes involving forest conversion, which does not include either rubber or swidden categories specifically, provides insights that are useful through analogy 
(Don et al. 2011): (a) transitions from forest to croplands and grasslands reduce carbon socks by $25-30$ and $12 \%$; (b) secondary forests contain $9 \%$ less carbon than primary forests; (c) afforestation of cropland increases SOC 29\%; and (d) fallowing and conversion of cropland to grasslands increases SOC 32\% and 26\%, respectively. In another review, Guo and Gifford (2002) determined transitions from forest to plantations decreased SOC on average by $13 \%$. Through analogy, we would expect that both swidden agriculture and rubber cultivation to have time-averaged SOC stocks that are in the neighbourhood of 9-13\% lower than forest.

In general, the greatest losses of SOC should occur shortly after the initial forest conversion and then approach equilibrium - this is likely true for swidden fields and rubber plantations alike (Murty et al 2002; Bruun et al. 2009). Immediate, long-lasting reductions in SOC should also result from soil excavations, for example terracing, to allow planting of rubber on steep slopes (Bruun et al. 2009). Unless cultivated swidden sites are severely degraded, fallowing should increase SOC on the order of $25 \%$ (assuming succession leads to grasslands or secondary forests). As newly planted rubber stands mature, SOC should also increase (from a value that resembles a cropland), although this increase may be less than that of fallowing because management of the rubber understory, including the removal of vegetation and fine/woody organic debris, likely limits carbon accumulation. In support, the modelling analysis of Gnanavelrajah et al. (2008) indicted the carbon accumulation rate for rubber was one of the lowest among 11 agriculture land-uses considered in Thailand.

With respect to recovery of soil carbon stocks after an initial transition, significant changes may not be recognizable over the course of one rotation of swidden fallow or rubber. In addition to initial carbon content, many other factors affect SOC at any location; i.e., climate, soil type, microbial communities, nitrogen cycling processes, and management (Murty et al. 2002). Importantly, differences between rubber and swidden SOC stocks are impossible to distinguish with this type of meta-analysis approach. However, even event site-specific data are problematic because the SOC values associated with any recent transition reflect, in part, the impact of former practices. Thus, as with AGC and BCG, differences in SOC between swidden and rubber lands are difficult to verify.

Given all the uncertainties regarding AGC, BGC, and SOC outlined above, we believe it is impossible to predict accurately the extent that REDD+ policies involving swidden-rubber transitions will ultimately increase carbon sequestration. Nonetheless, emerging carbon 
finance schemes are being developed across the tropics to provide economic incentives for more rural communities to transition away from swidden agriculture to other land use types, including rubber (FCPF 2010; UNREDD 2010; UNREDD Indonesia 2010). A recent case study in Laos exemplifies the current drama related to REDD, rubber, and swidden. In July 2009, the Lao-Thai Hua Rubber Company submitted a proposal to register some of its rubber plantations as an afforestation/reforestation project under the Clean Development Mechanism (LHTRC, 2007). This proposal triggered a lively debate among various stakeholders (public, private, NGOs, and development projects) whether rubber companies, often singled out as responsible for massive deforestation, could also benefit from Clean Development or REDD+ mechanisms for their perceived role in increasing carbon sequestration. In this example, the rubber company provided a preliminary analysis concluding that replacing traditional swiddens by rubber-based agro-forestry would provide a positive carbon outcome. Our analysis above suggests that unless end-member carbon stock values were used-e.g., those for short-value swidden or degraded swidden versus rubber growing in optimal conditionstransitions from swidden to rubber could only be viewed generally as neutral or uncertain in terms of changes in carbon sequestration.

On the other hand, conversion of some short-fallow systems with low carbon stocks to rubber may also be carbon positive. In addition, the replacement of truly degraded lands may also prove carbon positive - but care must be taken to prevent conversion of grasslands that are not degraded. Dewi et al (2009) concluded that oil palm in Indonesia should only be allowed to replace shrub and grasslands having AGC stocks $<40 \mathrm{Mg} / \mathrm{ha}$. A similar minimal threshold may also exist for rubber; and it may well be determined by specific biophysical conditions under which rubber is grown-importantly elevation. This minimum carbon biomass threshold should be approximately $13-35 \mathrm{Mg} / \mathrm{ha}$, which represents the low-end estimates for high-elevation rubber sites in Xishuangbanna (Li et al. 2008).

New site-specific carbon and other environmental assessments are needed to gain a more clear understanding of consequences of the demise of swiddening, the spread of rubber, and the role of REDD+ in MMSEA. Looking ahead, REDD+ implementation will require improved, cost-effective techniques for assessing plot and landscape-level carbon stocks. This is particularly important for below ground carbon, as this pool may be the critical deciding factor in determining optimal land use in terms of carbon sequestration. Uncertainties at both 
the plot and landscape scale are especially significant because many country REDD+ proposals world-wide target swidden farmers for exactly these types of land use transitions (FCPF 2010; UNREDD 2010).

Carbon sequestration aside, there are other important environmental issues to consider. Maintaining land under swidden agriculture can deliver superior biodiversity benefits compared with monoculture rubber plantations and some other agroforestry systems (Lawrence 2004; Rerkasem et al. 2009; Padoch and Pinedo-Vasquez 2010; Ziegler et al. 2011). Capital intensive farming methods that replace swiddening have their own set of environmental problems: e.g., accelerated erosion and landsliding on permanently converted hillslopes, degradation of stream water quality by pesticides and fertilizers, and stream desiccation caused by increased extraction of stream and groundwater for irrigation (Ziegler et al. 2009b). Furthermore, there is still great uncertainty regarding the potentially high water use of landscapes converted to alien monoculture plantations, particularly rubber in MMSEA (Guardiola-Claramonte et al. 2008, 2010; Qui et al. 2009; Ziegler et al. 2009a). These potential negative environmental consequences must also be balanced in REDD + dialogues (Padoch \& Pinedo-Vasquez 2010; Ziegler et al. 2011).

\section{Conclusions and Recommendations: Landscapes,}

\section{Livelihoods, and Carbon transitions in MMSEA}

Transitions from short-fallow systems and degraded lands to rubber could bring about both carbon and economic gains. Abandonment of swiddening to allow forest regeneration would undoubtedly increase carbon sequestration, but would produce negative economic consequences, unless offset with REDD+ payments. Furthermore, REDD+ incentives could also be applied to lengthening the fallow-period of existing swidden systems (e.g., transition from short- to intermediate/long-fallow swiddening or to other agroforestry systems). While these transitions are plausible, we question whether economic benefits would actually reach smallholders because the carbon volumes involved may be too limited to interest carbon investors. In Laos for example, government authorities have relocated villagers far from remaining forests on the belief that farmers would benefit from improved access to electricity, water, market, health and education infrastructures. As a result, the high carbon forests are under state management (e.g. national parks, national forest protection and production areas) 
while villagers are left with the management of poor forests under high population pressure. There is a therefore a real risk that REDD+ payments would not benefit poor households in marginal upland landscapes but the state, with unknown benefit sharing mechanisms.

To determine how great the REDD+ incentives would need to be in order to solicit a positive response from farm households it is necessary to consider the economic opportunity cost of the loss of any given agricultural activity. A recent economic analysis of rubber production in two provinces in Northeast Thailand (part of the non-traditional rubber growing area in MMSEA), determined the net benefit of rubber to farm households ranged from $\$ 1735$ to $\$ 2,226 /$ ha/year (Sawetwong and Dayananda 2008). Given that forests in MMSEA may sequester more carbon than rubber (we estimate approximately 20 to $200 \mathrm{Mg} \mathrm{C} /$ ha including AGC and BGC, but not SOC because soils are so variable — see discussion above), carbon payments would need to be on the order of $\$ 9.00$ to $\$ 111 / \mathrm{MgC}$ to entice farmers to not convert their forested swidden fallows to rubber. The European Union set fines for noncompliance of carbon emissions standards at $\$ 60 / \mathrm{MgC}$ excess $\mathrm{CO}_{2}$ emitted (Hill 2008), suggesting that a REDD+ policy might be able to pay farmers in less productive rubber growing areas (higher elevations, less rainfall) enough to cover their opportunity costs for participating in the program. Alternatively, the Cambodian government priced the carbon from its REDD projects at $\$ 3.00 / \mathrm{MgC}$ (Khun 2008); clearly not enough to solicit farmer participation in REDD projects.

The growing demand and market for natural rubber should continue to drive a transition from traditional farming systems and their associated secondary vegetation in MMSEA to landscapes dominated by rubber plantations. The impact of rubber on smallholders can range from being a viable and effective means for moving households and communities out of poverty to a proposition that causes farmers to struggle to maintain their lands or even to lose them to commercial investors and government institutions seeking to impose concession arrangements. We expect carbon markets will have diverse and often unexpected impacts on environmental governance and decision making when parachuted into this complex resource management situation. In addition to the unexpected impacts REDD + could have on livelihoods, too little is known about differences in carbon cycling among various types of swidden and replacement agriculture systems — including rubber — to know unequivocally which land-cover/land-use types provide the most viable basis for emissions mitigation. 
Given the difficulty of predicting the impact of land-use/land-cover change transitions on smallholders as well as on carbon stocks, it is highly risky, perhaps impossible, to suggest land-use policies that will ensure both reductions in terrestrial emissions and improvement in smallholder livelihoods. However, a few ideas can be suggested. In some parts of MMSEA, unprotected forests landscapes exist that can be managed under a REDD+ approach that focuses on protecting and improving carbon sequestration in standing forests. The 68,696 ha Oddar Meanchey Community Forestry REDD project in northwest Cambodia is an example of a REDD project on forest lands in MMSEA (Poffenberger and Smith-Hanssen 2009; Poffenberger 2009).

In other instances swidden agriculture may still be the most rational land use for farmers from both economic and environmental perspectives; and therefore, should be encouraged in areas where it contributes to the preservation of ecosystem services and cultural identity (Fox et al. 2009; Padoch \& Pinedo-Vasquez 2010; Ziegler et al. 2011). Thus, REDD+ policies should not preclude maintaining or rehabilitating traditional swidden systems with fallow periods that are sufficiently long to allow regeneration of mature secondary forests (Ziegler et al. 2011).

Still in other parts of the region secondary forest fallows will be converted to permanent agriculture, largely dominated by tree crops such as rubber, coffee, and cashews. A REDD+ project that seeks not only to increase carbon sequestration but also to improve the livelihoods of smallholders and to protect other environmental services such as biodiversity and soil and water conservation must provide economic support for small-scale, diversified, agroforestry systems, i.e. multi-storied agricultural systems that preserve the features and ecological functions of a forest, with great species diversity (De Foresta and Michon 1992).

If we look further afield than MMSEA, we find the example of jungle rubber in Indonesia. Defined as a complex agroforest, this system historically enabled millions of Indonesians to secure their livelihood while preserving the ecological features of a forest (Tomich et al. 2001; van Noordwijk et al. 1995, 1997). Today income per capita from jungle rubber is declining due to increased population density and lower productivity in comparison with monocrop, clonal rubber or oil plantations (Feintrenie and Levang 2009). Improved agroforestry solutions are needed to provide farmers with secure livelihoods without further endangering ecological and economic conditions. In addition to reducing carbon emissions, 
REDD + policies should support the development of complex agroforestry systems that provide secure livelihoods, and protect biodiversity and other ecosystem services.

Smallholders will require access to national agencies that provide technical support, extension, credit, transport and marketing of agroforestry products in order to both increase productivity of their land-use systems and reduce carbon emissions.

Finally, additional research is urgently needed to develop sound methodologies for assessing the impact of land-use transitions on carbon stocks as traditional swidden systems are replaced or transformed into other land-use practices_-including forest management efforts supported through REDD+ projects. From a carbon perspective, intermediate/long-fallow swidden systems could conceivably represent optimal land-use options in some situations. In addition, lengthening the fallow periods in existing swidden systems or managing the tree and bush phases of fallows more effectively may result in maximum carbon benefits. As some transitions from swidden to alternative land uses may produce undesirable negative impacts on ecosystem services and local livelihoods, both carbon and non-carbon benefits, as well as economic considerations, must be taken into account in the development of REDD + policies.

Like other land-use policies, the design of successful REDD+ policies will require the active involvement of local people in planning, implementing, monitoring and evaluating development and conservation programs in swidden lands. To be actively engaged smallholders need secure tenure for both agricultural and forest lands before they can participate in meaningful discussion with planners and government agencies concerning the future of their land. Positive market incentives and supportive government policies are better than standardized, top-down directives but opportunities and constraints for new land uses will be created by markets, national policies, and increasingly by global factors. Viable REDD + mechanisms must therefore strike a balance between carbon objectives and associated co-benefits when dealing with apparently similar carbon-positive land-use transitions. If carbon markets are to help rather than hinder local development, they must recognize the competing views and diversity of actors in environmental decision making and actively seek to include local people in decision making processes. 


\section{References}

Baird IG. 2010. Land, rubber and people: Rapid agrarian changes and responses in Southern Laos. The Journal of Lao Studies 1(1): 1-47.

Brown S, Lugo AE. 1990. Tropical secondary forests. Journal of Tropical Ecology 6: 1-32.

Bruun TB, de Neergaard A, Lawrence D and Ziegler AD. 2009. Environmental Consequences of the Demise in Swidden Agriculture in SE Asia: Soil Nutrients and carbon stocks. Human Ecology 37: 375-388.

Cairns M. (ed.). 2007. Voices from the Forest: Integrating Indigenous Knowledge into Sustainable Upland Farming. Resources for the Future: Washington.

Campbell BM. 2009. Beyond Copenhagen: REDD+, agriculture, adaptation strategies and poverty. Global Environmental Change 19: 397-399.

Castella JC, Bouahom B, Alberny E, DouangsavanhL. 2008. Emergence of a diversity of rubber regimes as outcome of local negotiations: A challenge for policy research. Policy Research Seminar - 22 Dec. 2008. NAFRI, Vientiane, Lao PDR.

Cheng C-M, Wang R-S, Jiang J-S. 2007. Variation of soil fertility and carbon sequestration by planting Hevea brasiliensis in Hainan Island, China. Journal of Environmental Sciences 19: 348-352.

De Foresta H and Michon G. 1992. Complex Agroforestry Systems and Conservation of Biological Diversity. Part 2: For a larger use of traditional agroforest trees as timber in Indonesia, a link between environmental conservation and economic development. In: Proceedings of the Symposium 'In Harmony with Nature', Kuala Lumpur, Malaysia.

Dewi S, Khasanah N, Rahayu S, Ekadinata A and van Noordwijk M. 2009. Carbon Footprint of Indonesian Palm Oil Production: a Pilot Study. Bogor, Indonesia: World Agroforestry. Centre - ICRAF, SEA Regional Office.

Don A, Schumacher J, Freibauer A. 2011. Impact of tropical land-use change on soil organic carbon stocks--a meta-analysis. Global Change Biology 17: 1658-1670.

Douangsavanh L, Hammavong B and Noble A. 2008. Meeting regional and global demands for rubber: A key to poverty alleviation in Laos? Bangkok, Thailand: The Sustainable Mekong Research Network (Sumernet).

Douangsavanh L. 2009. Investment Potential and Smallholding Development in Natural Rubber Industry in Laos. Paper prepared for Asean Rubber Conference, 18 - 20 Jun 2009. Vientiane, Laos.

Feintrenie L, and Levang P. 2009. Sumatra's rubber agroforests: advent, rise and fall of a sustainable cropping system. Small Scale Forestry 8(3): 323-335 
Forest Carbon Partnership Facility (FCPF). 2010. Readiness Preparation Proposals for: Socialist Republic of Vietnam, Nepal, Tanzania, Lao P.D.R. Democratic Republic of Congo. URL: www.forestcarbonpartnership.org/fcp/node/203.

Fox J, Fujita Y, Ngidang D, Peluso N, Potter L, Sakuntaladewi N, Sturgeon J, and Thomas D. 2009. Policies, Political-economy, and swidden in Southeast Asia. Human Ecology 37: 305-322.

Fox J, McMahon D, Poffenberger M, and Vogler J. 2008. Land for my Grandchildren: Land Use and Tenure Change in Ratanakiri: 1989-2007. Phnom Penh, Cambodia: Community Forestry International.

Fox J, and Castella JC. Submitted. Expansion of rubber (Hevea brasiliensis) in Mainland Southeast Asia: What are the prospects for smallholders? Journal of Peasant Studies.

Fox J, Vogler J, Sen OL, Ziegler AL and Giambelluca TW. Submitted. Simulating land-cover change in Montane Mainland Southeast Asia. Journal of Land Use Science.

Fukushima M, Kanzaki M, Hara M, Ohkubo T, Preechapanya P and Choocharoen C. 2008. Secondary forest succession after the cessation of swidden cultivation in the montane forest area in northern Thailand. Forest Ecology and Management 255: 1994-2006.

Geist HJ and EF Lambin. 2002. Proximate causes and underlying driving forces of tropical deforestation. Bioscience 52: 143-150.

Gibbs HK, Brown S, Niles JO and Foley JA. 2007. Monitoring and estimating tropical forest carbon stocks: making REDD a reality. Environmental Research Letters 2: 1-13.

Gnanavelrajah N, Shrestha RP, Schmidt-Vogt D, Samarakoon L. 2008. Carbon stock assessment and soil carbon management in agricultural land-uses in Thailand. Land Degradation and Development 19: 242-256.

Guardiola-Claramonte MP, Troch A, Ziegler AD, Giambelluca TW, Vogler JB and Nullet MA. 2008. Local hydrologic effects of introducing non-native vegetation in a tropical catchment. Ecohydrology 1:13-22, doi:10.1002/eco.3.

Guardiola-Claramonte M, Troch PA, Ziegler AD, Giambelluca TW, Durcik M, Vogler JB, Nullet MA. 2010. Modeling basin-scale hydrologic effects of rubber (Hevea brasiliensis) in a tropical catchment. Ecohydrology. DOI: 10.1002/eco.110

Guo LB and Gifford RM. 2002. Soil carbon stocks and land use change: a meta-analysis. Global Change Biology 8: 345-360.

Hill R. 2008. REDD myths: A critical review of proposed mechanisms to reduce emissions from deforestation and degradation in developing countries. Friends of the Earth 114: 142.

Jepson M.R. 2006. Above-ground carbon stocks in tropical fallows, Sarawak, Malaysia. Forest Ecology and Management 225: 287-295. 
Kenzo T, Ichie T, Hattori D, Itioka T, Handa C, Ohkubo T, Kendawang JJ, Nakamura M, Sakgucki M, Takahashi N, Okamoto M, Tanaka-Oda A, Sakurai K and Ninomiya I. 2009. Development of allometric relationships for accurate estimation of above- and belowground biomass in tropical secondary forests in Sarawak, Malaysia. Journal of Tropical Ecology 25: 371-386.

Khun V. 2008. Methods currently used in Cambodia for forest inventory. Cambodian Government report present at 'Managing forests in Mekong Countries for Carbon Sequestration and REDD’ Workshop. Hanoi 3-6 November 2008.

Lawrence D. 2004. Land-use change, biodiversity and ecosystem functioning in West Kalimantan. In: Land Use, Nature Conservation and the Stability of Rainforest Margins in Southeast Asia. Gerold G, Fremery M and Guhardja E, eds. Springer-Verlag, Berlin pp. 253-268.

Lawrence D. 2005. Biomass accumulation after 10 to 200 years of shifting cultivation in Bornean rainforest. Ecology 86: 26-33.

Lawrence D, Suma V, Mogea JP. 2005. Change in species composition with repeated shifting cultivation: limited role of soil nutrients. Ecological Applications 15: 1952-1967.

Lawrence D, Radel C, Tully K, Schook B, Schneider L. 2010. Untangling a Decline in Tropical Forest Resilience: Constraints on the Sustainability of Shifting Cultivation Across the Globe. Biotropica 42: 21-30.

LHTRC. 2007. Lao Thai Hua Rubber Company Ltd. CEM Rubber reforestation Pilot. http://laothaihuarubber.com/.

Li H, Ma Y, Aide TM and Liu W. 2008. Past, present and future land-use in Xishuangbanna, China and the implications for carbon dynamics. Forest Ecology and Management 225: 16-24.

Li Z and Fox J. 2011. Mapping rubber in Mainland Southeast Asia using time-series MODIS $250 \mathrm{~m}$ NDVI and statistical data. Applied Geography 32: 420-432.

Lugo A and Brown S. 1992. Tropical forests as sinks of atmospheric carbon. Forest Ecology and Management 54: 239-255.

Lu X-T, Yin J-X, Jepsen MR, Tang J-W. 2010. Ecosystem carbon storage and partitioning in a tropical seasonal forest in southwestern China. Forest Ecology and Management 260: 1798-1803.

Majid-Cooke F. 2003. Maps and counter maps: Globalised imaginings and local realities of Sarawak's plantation agriculture. Journal of Southeast Asian Studies 34:265-284.

Majid-Cooke F. 2006. Expanding state spaces using "idle" native customary land in Sarawak' In: Majid-Cooke F, ed. State, Communities and Forest in Contemporary Borneo. AsiaPacific Environment Monograph 1. Canberra: ANU E Press. p 25-44. 
Mertz O. 2009. Trends in shifting cultivation and the REDD mechanism. Current Opinion in Environmental Sustainability 1: 156-160.

Messerli PA, Heinimann M and Epprecht M. 2009. Finding homogeneity in heterogeneity-a new approach to quantifying landscape mosaics developed for the Laos. Human Ecology 37: 191-304.

Michon G, De Foresta H, Levang P and Verdeaux F. 2007. Domestic forests: a new paradigm for integrating local communities' forestry into tropical forest science. Ecology and Society 12(2):1-24.

Mizoue N, Kakada K, Muthavy K, Gyokusen K, Koga S, Shigematsu A, Yoshida S. 2009. Multiple functions of rubber plantations as forest and wood resources - project progress report. T21: Sustainable production from manmade forests in the tropics. 120th Forest Congress in Kyoto.

Murty D, Kirschbaum MUF, McMurtrie RE and McGilvray H. 2002. Does conversion of forest to agricultural land change soil carbon and nitrogen? A literature review. Global Change Biology 8: 105-123.

Negra C and Wollenberg E. 2011. Lessons from REDD+ for Agriculture. CCAFS Policy Brief no. 1. CGIAR Research Program, Climate Change, Agriculture and Food Security (CCAFS). Copenhagen, Denmark. Available online at:www.ccafs.cgiar.org

Ngidang D. 1997. Native customary land rights, public policy, land reform and plantation development in Sarawak. Borneo Review VIII (1): 63-80.

Ngidang D. 2002. Contradiction in land development schemes: The Case of joint ventures in Sarawak, Malaysia. Asia Pacific Viewpoint 43 (2): 157-180.

Nikolic N, Schultze-kraft R, Nicolic M, Böcker R, Holz I. 2008. Land degradation on barren hills: a case study in northeast Vietnam. Environmental Management 42: 19-36.

Padoch C, Coffey K, Mertz O, Leisz SJ, Fox J and Wadley RL. 2007. The demise of swidden in Southeast Asia? Local realities and regional ambiguities. Geografisk Tidsskrift-Danish Journal of Geography 107: 29-4.

Padoch C and Pinedo-Vasquez M. 2010. Saving swidden to save biodiversity. Biotropica 42: $550-552$.

Palm CA, van Noordwijk M, Woomer P, Alegre JC, Arévalo L, Castilla CE, Cordeiro DG, Hairiah K, Kotto-Same J, Moukam A, Parton WJ, Ricse A, Rodrigues V and Sitompul SM. 2005. Carbon losses and sequestration after land use changes on the humid tropics. In: Palm CA, Vosti SA, Sanchez PA and Ericksen PJ, eds. Slash-and-Burn Agriculture: The Search for Alternatives. Columbia University Press, New York, pp. 41-63.

Poffenberger M and Smith-Hanssen K. 2009. Forest Communities and REDD Climate Initiatives. AsiaPacific /ssues, No. 91. 
Poffenberger M. 2009. Cambodia's forests and climate change: Mitigating drivers of deforestation. National Resources Forum 33: 285-296.

Prachaya J. 2009. Rubber Economist Quarterly Report. London and Bangkok.

Qui J. 2009. Where the rubber meets the garden. Nature 457: 246-247.

Rubber Board. 2005. Rubber Growers Companion. Government of India, Kottayam, Kerala, India: 115.

Ramakrishnan PS, Saxena KG, Rao KS. 2006. Shifting Agriculture and Sustainable Development of northeastern India: Tradition in Transition. New Delhi, India: Oxford and IBH Publishing Co. Pvt. 495 pp.

Ramakrishnan PS. 2007. Traditional forest knowledge and sustainable forestry: A northeast India perspective. Forest Ecology and Management 249: 91-99.

Rasul G and Thapa GB. 2003. Shifting cultivation in the mountains of South and Southeast Asia: regional patterns and factors influencing the change. Land Degradation and Development 14: 495-508.

Rerkasem K, Lawrence D, Padoch C, Schmidt-Vogt D, Ziegler AD. 2009. Consequences of swidden transitions for crop and fallow biodiversity. Human Ecology 37: 347-360.

Ribot J and Peluso N. 2003. A theory of access. Rural Sociology 68(2): 153-181.

Sabhasri S. 1978. Effects of forest fallow cultivation on forest production and soil. Chapter 8, pp. 160-184 In: Kunstadter P, Chapman EC and Sabhasri S, eds. Farmers in the Forest: Economic development and marginal agriculture in Northern Thailand. East-West Center: Honolulu, Hawaii.

Sawetwong B and Dayananda C. 2008. The comparison of para rubber in terms of marketing and production between Khon Kaen and Nhong Kai provinces in 2007. Khon Kaen Agricultural Journa/36: 241-246 (in Thai).

Schmidt-Vogt D. 2001. Secondary forests in swidden agriculture in the highlands of Thailand. Journal of Tropical Forest Science 12 : 748-767.

Schmidt-Vogt D, Leisz SJ, Mertz O, Heinimann A, Thiha T, Messerli P, Epprecht M, Cu PV, Chi VK, Hardiono M and Dao TM. 2009. An Assessment of Trends in the Extent of Swidden in Southeast Asia. Human Ecology 37: 269-280.

Shi W. 2008. Rubber Boom in Luang Namtha: A Transnational Perspective, Deutsche Gesellschaft fuer Technische Zusammenarbeit (GTZ), February.

Sturgeon J. 2010. Governing minorities and development in Xishuangbanna, China: Akha and Dai rubber farmers as entrepreneurs. Geoforum 41:318-328

Tomich TP, van Noordwijk M, Vosti SA and Witcover J. 2001. Agricultural Development with Rainforest Conservation Methods for Seeking Best Bet Alternatives to Slash-and- 
Burn, with Applications to Brazil and Indonesia. Journal of Agricultural Economics 19: 159-174.

Undercurrents. 2009. Rubber mania: Scrambling to supply China, Can ordinary farmers benefit? URL:

www.burmariversnetwork.org/images/stories/publications/english/undercurrentsissue3.pdf

UNFCCC. 2009. United Nations Framework Convention on Climate Change. Copenhagen Accord. Conference of the Parties Fifteenth session, December 7-18, Copenhagen, Denmark. URL: www.unfccc.intermediate/resource/docs/ 2009/cop15/eng/107.pdf. UNREDD. 2010. United Nations REDD Programme. Slash and burn farming. URL: www.unredd.org/NewsCentre/Slash and_Burn_Farming/tabid/3013/Default.aspx

UNREDD Indonesia. 2010. Indonesia National Strategy for the Reduction of Emissions from Deforestation and Forest Degradation Draft 1 Revised. URL: www.un.or.id/redd. van Noordwijk M, van Schaik CP, de Foresta H and Tomich TP. 1995. Segregate or integrate for biodiversity conservation? Paper presented at the Global Biodiversity Forum, Jakarta, Indonesia, 4-5 November.

van Noordwijk, M., T.P. Tomich, H. de Foresta and G. Michon. 1997. To Segregate or to Integrate? The Question of Balance between Production and Biodiversity Conservation in Complex Agroforestry Systems. Agroforestry Today 9(1): 6-9.

van Noordwijk M, Minang PA, Dewi S, Hall J, Rantala S. 2009. Reducing Emissions from A/l Land Uses (REALU): The Case for a whole landscape approach. ASB Policy Brief 13. ASB Partnership for the Tropical Forest Margins, Nairobi, Kenya.

van Noordwijk M, Hairriah K and Sitompul SM. 2000. Reducing uncertainties in the assessment at national scale of $\mathrm{C}$ stock impacts of land use change. Proceedings of IGES/NIESWorkshop on GHG Inventories for Asia-Pacific Region, 9-10 March 2000. Retrieved October 182006 from www.gcte.org/MeetRep(3)-UncertCstockMaine'spaper.pdf.

Viswanathan PK and Shivakoti GP. 2008. Adoption of rubber-integrated farm-livelihood systems: Contrasting empirical evidence from the Indian context. Journal of Forest Research 13:1-14.

Wauters JB, Coudert S, Grallilen E, Jonard M and Ponette Q. 2008. Carbon stock in rubber tree plantations in Western Ghana and Mato Grosso (Brazil). Forest Ecology and Management 255: 2347-2361.

Xu J, Fox J, Melick D, Fujita Y, Jintrawet A, Jie Q, Thomas D, Weyerhaeuser H. 2006. Land use transition, livelihoods, and environmental services in Montane Mainland Southeast Asia. Mountain Research and Development 26(3):278-284. 
Yamakura T, Hagihara A, Sukardjo A, Ogawa H. 1986. Aboveground biomass of tropical rain forest stands in Indonesia Borneo. Vegetatio 68: 71-82.

Zheng Z, Feng Z, Cao M, Li Z, Zhang J. 2006. Forest structure and biomass of a tropical seasonal rain forest in Xishuangbanna Southwest China. Biotropica 38: 318-327.

Ziegler AD, Fox J and Xu J. 2009a. The rubber juggernaut. Science 324: 1024-1025.

Ziegler AD, Bruun TB, Guardiola-Claramonte M, Giambelluca TW, Lawrence D and Lam NT. 2009b. Environmental Consequences of the Demise in Swidden Agriculture in SE Asia: Hydrology and Geomorphology. Human Ecology 37: 361-373. DOI 10.1007/s10745-009-9258-x

Ziegler AD, Fox J, Webb EL, Padoch C, Leisz S, Cramb RA, Mertz O, Bruun TB, Vien TD. 2011. Recognizing contemporary roles of swidden agriculture in transforming landscapes of Southeast Asia. Conservation Biology 25(4): 846-848. 


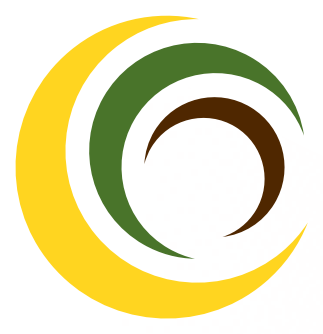

The CGIAR Research Program on Climate Change, Agriculture and Food Security (CCAFS) is a strategic initiative of the Consultative Group on International Agricultural Research (CGIAR) and the Earth System Science Partnership (ESSP), led by the International Center for Tropical Agriculture (CIAT). CCAFS is the world's most comprehensive global research program to examine and address the critical interactions between climate change, agriculture and food security.

\section{For more information, visit www.ccafs.cgiar.org}

Titles in this Working Paper series aim to disseminate interim climate change, agriculture and food security research and practices and stimulate feedback from the scientific community.
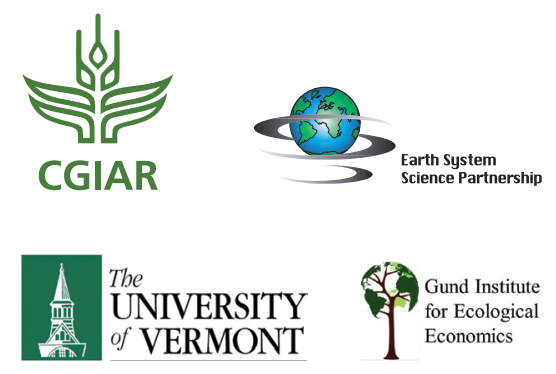

\section{류 $\mathrm{ClAT}$

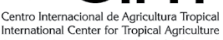

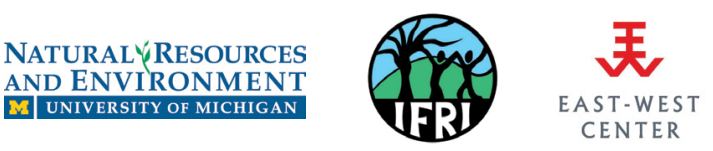

